DOI

\title{
ЕКОНОМІЧНІ МЕХАНІЗМИ СТВОРЕННЯ ЄДИНОГО МЕДИЧНОГО ПРОСТОРУ В УКРАÏHI
}

\author{
ДУ “Український інститут стратегічних досліджень МОЗ України”, м. Київ
}

\begin{abstract}
Мета: висвітлення основних цілей та орієнтирів економічних механізмів створення єдиного медичного простору; проведення порівняльного аналізу впровадження нових організаційно-правових та фрінансово-економічних механізмів, спрямованих на підвищення ефективності та доступності медичного обслуговування населення.

Матеріали і методи. Були використані статистичні дані пілотних регіонів; застосовані економічний, статистичний, методи порівняльного аналізу.

Результати. Основою підвищення ефективності системи охорони здоров'я є удосконалення її організаційноекономічного механізму - сукупності фрорм, методів і механізмів, за допомогою яких здійснюється організація суспільного виробництва в ссрері охорони здоров'я й узгоджується економічно доцільна їі діяльність як єдиної системи. На прикладі пілотних регіонів показані нові підходи до організації роботи закладів охорони здоров'я та їх кадрового забезпечення.

Висновки. Державна політикащодо реформування охорони здоров'я має бути спрямована на фрормування моделі, що відповідає соціально-економічним реаліям України. Необхідно запровадити набутий досвід ресормування системи охорони здоров'я в пілотних регіонах на національному рівні.
\end{abstract}

КЛЮчОВІ СЛОВА: єдиний медичний простір, пілотні регіони, ефективність, якість медичної допомоги.

Економічний розвиток будь-якої держави значною мірою залежить від стану здоров'я її населення. За останні десятиріччя в політичному та економічному житті України відбулися великі зміни, які зумовили необхідність розробки і прийняття нової концепції розвитку системи охорони здоров'я, організації медичних послуг і відповідних програм розвитку. У контексті цієї концепції мають відображатися і концентруватися всі суспільно-політичні, економічні, соціальні та інші проблеми, які потребують вирішення на законодавчо-нормативному, науковометодичному та організаційно-економічному рівнях. Організаційно-економічний механізм розвитку галузі потребує удосконалення для забезпечення найкращих результатів якості, доступності медичної допомоги, поліпшення показників здоров'я населення при відносно незначних витратах ресурсів.

Мета даного дослідження полягає у висвітленні основних цілей та орієнтирів економічних механізмів створення єдиного медичного простору, проведенні порівняльного аналізу впровадження нових організаційно-правових та фрінансово-економічних механізмів, спрямованих на підвищення ефективності та доступності медичного обслуговування населення, які є необхідними для розвитку системи охорони здоров'я України.

Матеріали і методи. При написанні статті були використані наступні методи дослідження: бібліографічний, статистичний, порівняльного аналізу.

Результати дослідження та їх обговорення. Охорона здоров'я - це пріоритетне питання наці-

(с) О.М. Дзюба, Н.Т. Кучеренко, 2015 ональної безпеки України, одним із завдань якої $\epsilon$ підвищення ефрективності економічних механізмів управління 3 метою поліпшення здоров'я населення, забезпечення рівного доступу громадян до медичних високоякісних послуг, а отже створення єдиного медичного простору.

Система охорони здоров'я може бути есрективною лише за умови її трансформації на економічноправових засадах і на найширшому впровадженні інфрормаційних технологій. Ключовою фрігурою в системі має стати лікар загальної практики, який спільно з пацієнтом несе солідарну відповідальність за стан його здоров'я. Система управління галуззю має ґрунтуватися на медичній економіці [1].

Одним із сегментів єдиного медичного простору стало реформування системи охорони здоров'я в пілотних регіонах України.

Рішення про проведення ресоорми було прийнято Законом України № 3612 від 7 липня 2011 року «Про порядок проведення реформування системи охорони здоров'я у Вінницькій, Дніпропетровській, Донецькій областях та місті Києві» [2]. Цей Закон визначає структурно-організаційні та правові засади ресрормування системи охорони здоров'я у зазначених регіонах, що дасть змогу:

- підвищити рівень медичного обслуговування населення, розширити можливості щодо його доступності та якості;

- впровадити нові підходи до організації роботи закладів охорони здоров'я у пілотних регіонах та їх фрінансового забезпечення;

- підвищити ефективність використання бюджетних коштів, передбачених для фрінансового 
забезпечення системи охорони здоров'я у пілотних регіонах.

Наказом МОЗ України № 494 від 11.06.2013 р. «Про удосконалення моніторингу реформи системи охорони здоров'я» затверджено показники, що подаються пілотними регіонами для проведення оцінки стану реформування системи охорони здоров'я, за якими щорічно проводиться узагальнення інформації та аналіз стану реформування галузі [3].

У 2014 р. закінчено процеси розмежування первинного і вторинного рівнів надання медичної допомоги і створення Центрів первинної медикосанітарної допомоги (ЦПМСД) - усього 114 (дані наведені без Донецької області). У звітному році у м. Києві фрункціонує 28 ЦПМСД, 3 них у пілотних районах 9, в інших - 19 (табл. 1).

У Дніпропетровській області більшість ЦПМСД створено у містах, у Вінницькій - у сільських районах, що пов'язано із адміністративнотериторіальним устроєм цих областей та існуючими географічними особливостями розселення населення.

Таблиця 1. Кількість цпмсД у пілотних регіонах, 2014 р.

\begin{tabular}{|c|c|c|c|}
\hline Назва показника & Дніпропетровська & Вінницька & м. Київ \\
\hline $\begin{array}{l}\text { Кількість створених ЦПМСД зі статусом юридичної особи } \\
\text { у містах, од. }\end{array}$ & 30 & 6 & 28 \\
\hline $\begin{array}{l}\text { Кількість створених ЦПМСД зі статусом юридичної особи } \\
\text { у сільських районах, од. }\end{array}$ & 23 & 27 & $x$ \\
\hline $\begin{array}{l}\text { Усього ЦПМСД у розрізі кожного пілотного регіону } \\
\text { (міста/сільські райони) }\end{array}$ & 53 & 33 & 28 \\
\hline Усього ЦПМСД у пілотних регіонах & \multicolumn{3}{|c|}{114} \\
\hline
\end{tabular}

Особливістю створення та фрункціонування ЦПМСД у м. Києві є їх господарський статус - у формі комунальних неприбуткових підприємств. У інших пілотних регіонах ЦПМСД створені і функціонують як бюджетні установи [4].

Кадровий потенціал для надання первинної медичної допомоги (ПМД) у пілотних регіонах $€$ наступним.

У Дніпропетровській області ПМД надавалася 1537 лікарями, укомплектованість штатних посад лікарів фрізичними особами - 74,1\%. У містах у ЦПМСД працювало 1134 лікарі, у сільських районах - 403; укомплектованість штатних посад лікарів фізичними особами у містах становить 77,0\%, у сільських районах - 66,8\%. Чисельність лікарів загальної практики - сімейних лікарів (ЛЗПСЛ) становила 1226, у т.ч. у містах - 853, у сільських районах - 373. Укомплектованість штатних по- сад ЛзПСл фрізичними особами в області - 76,0\%, у т.ч. у містах - 80,3\%, сільських районах - 67,8\%.

У Вінницькій області ПМД надавалася 953 лікарями, укомплектованість штатних посад лікарів фрізичними особами становила 79,7\%. У містах у ЦПМСД працювало 573 лікарі, у сільських районах - 380; укомплектованість штатних посад лікарів фрізичними особами у містах - 89,0\%, у сільських районах - 69,0\%. Чисельність ЛЗПСЛ становила 832, у т.ч. у містах - 470, у сільських районах 362. Укомплектованість штатних посад ЛЗПСЛ фрізичними особами в області становила 79,4\%, у т.ч. у містах - 90,0\%, у сільських районах - 68,9\%.

У м. Києві ПМД надавалася 1546 лікарями, укомплектованість штатних посад лікарів фрізичними особами становила 73,1\%. Чисельність ЛЗПСЛ становила 667, укомплектованість штатних посад фрізичними особами - 74,8\% (табл. 2).

Таблиця 2. Дані про лікарські кадри, які надавали пМД у Центрах ПМСд

\begin{tabular}{|c|c|c|c|c|c|c|c|c|}
\hline Показник & 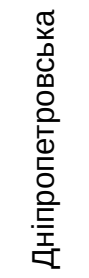 & 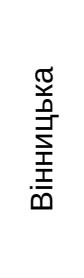 & $\begin{array}{l}: \stackrel{\varrho}{\vec{\Sigma}} \\
\dot{\Sigma}\end{array}$ & 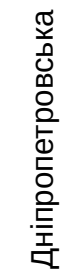 & 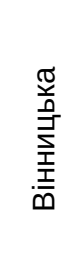 & $\begin{array}{l}: \frac{\varrho}{\Sigma} \\
\dot{\Sigma} \\
\dot{\Sigma}\end{array}$ & 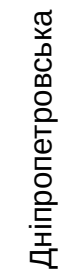 & 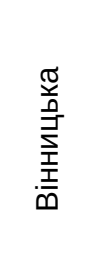 \\
\hline & \multicolumn{3}{|c|}{ усього } & \multicolumn{3}{|c|}{ у містах } & \multicolumn{2}{|c|}{$\begin{array}{l}\text { у сільських } \\
\text { районах }\end{array}$} \\
\hline Кількість лікарів, що надають ПМД, фрізичних осіб & 1537 & 953 & 1546 & 1134 & 573 & 1546 & 403 & 380 \\
\hline Кількість ЛЗПСЛ, фрізичних осіб & 1226 & 832 & 667 & 853 & 470 & 667 & 373 & 362 \\
\hline $\begin{array}{l}\text { Укомплектованість штатних посад лікарів, які на- } \\
\text { дають ПМСД, фрізичними особами -лікарями, \% }\end{array}$ & 74,1 & 79,7 & 73,1 & 77,1 & 89,0 & 73,1 & 66,8 & 69,0 \\
\hline $\begin{array}{l}\text { Укомплектованість штатних посад ЛЗПСЛ фрізич- } \\
\text { ними особами - ЛЗПСЛ, \% }\end{array}$ & 76,0 & 79,4 & 74,8 & 80,3 & 90,0 & 74,8 & 67,8 & 68,90 \\
\hline
\end{tabular}


Аналіз отриманих даних з ресрормування ПМД у пілотних регіонах свідчить про певні позитивні зрушення у напрямку покращення рівня кадрового забезпечення:

- у Дніпропетровській області чисельність ЛЗПСЛ зросла з 1068 у 2013 р. до 1226 у 2014 р., відповідно на 10 тис. нас. - 3 3,2 у 2013 р. до 3,7 у 2014 р.;

- у Вінницькій області чисельність ЛЗПСЛ зросла з 750 у 2013 р. до 832 у 2014 р., відповідно на 10 тис. нас. -3 4,63 у 2013 р. до 5,2 у 2014 р.;

- у м. Києві чисельність ЛЗПСЛ зросла з 503 у 2013 р. до 667 у 2014 р., відповідно на 10 тис. нас. - 31,8 у 2013 р. до 2,3 у 2014 р.

У Дніпропетровській області ПМД надавалася лЗПСЛ, їх питома вага у загальній кількості лікарів, які займаються лікувальною справою, становила $79,8 \%$, у Вінницькій - 84,7\%, у м. Києві - 43,2\%.

Первинна медична допомога у Дніпропетровській області надавалася лзпсл 79,8\% населення, у Вінницькій - 93,0\%, у м. Києві - 51,9\%, тобто рівень охоплення цим видом медичної допомоги був найвищим у Вінницькій області, найнижчим -у м. Києві.

Аналіз рівня навантаження на лікарів, які надавали ПМД, засвідчив, що у всіх пілотних регіонах фрактичне навантаження в розрахунку на одного лікаря (фрізичну особу) перевищувало нормативні показники як у містах, так і у сільських районах, особливо це стосувалося дільничних терапевтів (особливо в містах Дніпропетровської області відповідно 3682). Найнижчі рівні навантаження на дільничних педіатрів спостерігалися у містах та сільських районах Вінницької області - 853 та 704 осіб відповідно.

Рівень навантаження на одного ЛЗПСЛ становив:

- у Дніпропетровській області - 2050 осіб у містах і 2133 осіб у сільських районах;

- у Вінницькій області - 1562 особи у містах і 2183 особи у сільських районах;

- у м. Києві - 2504 осіб.

Співвідношенням штатних посад лікарів ПМСД до штатних посад молодших працівників з медичною освітою у закладах ПМСД було найвищим у Вінницькій області $(1: 2,6)$ у Дніпропетровський на рівні 1:1,6; у м. Києві -1:0,66.

Щодо доступності лікарських засобів для сільського населення, у звітному році у Дніпропетровській і Вінницькій областях збільшено мережу пунктів реалізації лікарських засобів (Дніпропетровська - 93,1\%; Вінницька - 62,0\% від їх загальної чисельності).

Найвищі рівні видатків на надання ПМД у розрахунку на одного жителя виявилися у м. Києві (250,3 грн), найнижчі-у Вінницькій області (229,77 грн). На ПМД від зведеного бюджету (загальний бюджет та спеціальний фонд) у Вінницькій області спрямовано 22,1\% видатків, у м. Києві - 18,6\%.
У пілотних регіонах триває робота з оптимізації ліжкового фронду. Забезпеченість ліжками становила: у Вінницькій області - 40,0 на 10 тис. нас., у Дніпропетровській області та м. Києві - 62,54 та 62,9 відповідно.

У Вінницькій області 64,5\% оперативних втручань від загальної кількості оперативних втручань проведено в амбулаторно-поліклінічних умовах (включаючи «хірургію одного дня»), у м. Києві 46,5\%, у Дніпропетровській області - 43,9\%.

Найвищий рівень летальності та післяопераційної летальності спостерігався у м. Києві (відповідно 1,67 та 0,87), найнижчий - у Вінницькій області (відповідно 0,9 та 0,3).

Центри екстреної медичної допомоги та медицини катастрофр функціонували у всіх пілотних регіонах [5]. Тривало створення оперативнодиспетчерської служби у Дніпропетровській та Вінницькій областях. У м. Києві створена Єдина оперативно-диспетчерська служба (перша черга), проводилася робота із впровадження другої черги Національного проекту «Вчасна допомога» - підключення до Єдиної оперативно-диспетчерської служби міста Києва на базі Центру екстреної медичної допомоги та медицини катастроф міста Києва.

У Дніпропетровській області створено 81 пункт постійного/тимчасового базування (план виконання 100\%); у Вінницькій - 40 пунктів (план виконання 100\%); у м. Києві - 29 пунктів (план виконання 100\%).

У Дніпропетровській області забезпеченість населення бригадами екстреної (швидкої) медичної допомоги становила 0,84; у Вінницькій - 0,74; у м. Києві - 0,46 бригади на 10 тис. населення.

У Дніпропетровській та Вінницькій областях медична допомога надавалася фрельдшерськими бригадами екстреної (швидкої) медичної допомоги, частка яких у їх загальній чисельності становила 65,7\% та 54,5\% відповідно; у м. Києві - переважно лікарськими бригадами (частка - 83,9\%). У закладах охорони здоров'я, що надають екстрену медичну допомогу, укомплектованість штатних посад лікарів фрізичними особами найвища у Вінницькій області (77,35\%), найнижча - у Дніпропетровській $(55,1 \%)$; штатних посад лікарів зайнятими - найвища у м. Києві (100\%), найнижча - у Дніпропетровській області $(81,0)$. За рівнем укомплектованості штатних посад молодших медичних працівників 3 медичною освітою фрізичними особами лідирують Вінницька область $(97,6 \%)$ та м. Київ (89,0\%).

Кількість викликів екстреної (швидкої) медичної допомоги становила у Дніпропетровській області 260 на 1000 населення, у м. Києві - 175,7 на 1000 населення.

Показники чисельності населення, яке в середньому обслуговує один лікар, що надає первинну медичну допомогу (дільничний терапевт, дільничний педіатр, лікар загальної практики-сімейний лі- 
кар), у Дніпропетровській області складали 2072 особи, у м. Києві - 2009; найнижчі у Вінницькій області - 1785 .

Показник проведених оперативних втручань у стаціонарах на 10 тис. нас. у Дніпропетровській області становив 593,2, у Вінницькій - 564,3, у м. Києві - 560,1.

\section{Висновки}

Таким чином, проведений порівняльний аналіз засвідчив створення на базі існуючої у пілотних регіонах мережі закладів охорони здоров'я структурованої за видами медичної допомоги системи медичного обслуговування шляхом відокремлення (або об'єднання) закладів охорони здоров'я, які задовольняють потреби населення у первинній, вторинній та екстреній медичній допомозі. Організовано та забезпечено функціонування у пілотних регіонах Центрів первинної медичної (медикосанітарної) допомоги для задоволення потреб населення у такому виді медичної допомоги. Здійснюється перепрофрілювання закладів охорони здоров'я пілотних регіонів, що надають вторинну (спеціалізовану) медичну допомогу, з урахуванням інтенсивності її надання, а також створення Центрів екстреної медичної допомоги. Організована діяльність госпітальних округів, які забезпечують умови для надання населенню вторинної (спеціалізованої) медичної допомоги. Проводиться перерозподіл ресурсів між закладами охорони здоров'я пілотних регіонів, що надають первинну, вторинну (спеціалізовану) та екстрену медичну допомогу на території зазначених регіонів.

Перспективи подальших досліджень. Державна політика щодо реформування охорони здоров'я має бути спрямована на фрормування моделі, що найбільш відповідає соціально-економічним реаліям України. При цьому головним завданням $€$ створення механізмів підвищення рівня медичного обслуговування населення, розширення можливості щодо його доступності та якості. Необхідно запровадити набутий досвід реформування системи охорони здоров'я в пілотних регіонах на національному рівні. Результатом цього повинні стати якісні, позитивні зміни не тільки функцій, але й структури системи охорони здоров'я в цілому.

\section{Список літератури}

1. Голунов А. І. Економічні перспективи щодо реформування галузі та використання сучасних технологій в управлінні первинною медико-санітарною допомогою / А. І. Голунов // Актуальні питання подальшого розвитку сімейної медицини в Україні. - Київ, 2004.

2. Про порядок проведення реформування системи охорони здоров'я у Вінницькій, Дніпропетровській, Донецькій областях та місті Києві : Закон України № 3612 від 7 липня 2011 року [Електронний документ]. - Режим доступу : http://zakon2.rada.gov.ua/laws/show/3612-17. - Назва з екрану.

3. Про удосконалення моніторингу ресорми системи охорони здоров'я : наказ МОЗ України № 494 від 11.06.2013 р. [Електронний документ]. - Режим доступу: www.moz.gov.ua/ua/portal/dn_20130611_0494.html - Назва $з$ екрану.

4. Шевченко М. В. Результати ходу реформування первинної ланки надання медичної допомоги населенню у пілотних регіонах/М.В. Шевченко, Ю. Б. Ященко// Східноєвропейськийжурн. громад. здоров’я. -2013. - № 1 (21). C. $289-290$.

5. Шевченко М. В. Стан реформування екстреної медичної допомоги у пілотних регіонах у 2012 р. / М. В. Шевченко, Ю. Б. Ященко // Східноєвропейський журн. громад. здоров'я. - 2013. - № 1 (21). - С. 291.

\section{ЭКОНОМИЧЕСКИЕ МЕХАНИЗМЫ СОЗДАНИЯ ЕДИНОГО МЕДИЦИНСКОГО ПРОСТРАНСТВА В УКРАИНЕ}

А.Н. Дзюба, Н.Т. Кучеренко

ГУ «Украинский институт стратегических исследований МОЗ Украины», г. Киев

Цель: освещение основных целей и ориентиров экономических механизмов создания единого медицинского пространства, проведение сравнительного анализа внедрения новых организационноправовых и фринансово-экономических механизмов, направленных на повышение эффективности и доступности медицинского обслуживания населения.

Материалы и методы. Были использованы статистические данные пилотных регионов; применены экономический, статистический, методы сравнительного анализа.

Результаты. Основой повышения эффективности системы здравоохранения является совершенствование ее организационно-экономического механизма - совокупности форм, методов и механизмов, с помощью которых осуществляется организация общественного производства в сфере здравоохранения и согласуется экономически целесообразная ее деятельность как единой системы. На примере пилотных регионов показаны новые подходы к организации работы учреждений здравоохранения и их кадрового обеспечения.

Выводы. Государственная политика относительно реформирования здравоохранения должна быть направлена на фрормирование модели, которая соответствует социально-экономическим реалиям Украины. Необходимо внедрить приобретенный опыт редормирования системы здравоохранения в пилотных регионах на национальном уровне.

КЛЮЧЕВЫЕ СЛОВА: единое медицинское пространство, пилотные регионы, эффективность, качество медицинской помощи. 


\section{ECONOMIC MECHANISMS OF CREATION OF UNIFORM MEDICAL SPACE IN UKRAINE}

O.M. Dziuba, N.T. Kucherenko

PE «Ukrainian Institute of Strategic Researches MHC of Ukraine», Kyiv

Purpose. Coverage of the basic purposes and objectives of economic mechanisms of creation of uniform medical space, carrying out of the comparative analysis of implementation of the new organizational, legal, financial and economic mechanisms.

Materials and methods. Comparative analysis, economic, statistical methods are applied.

Results. Basis of increase of system effectiveness of health care system is perfection of its organizational and economic mechanism with which will be coordinated its activity as uniform system. By the example of pilot regions new approaches to the organization of health care institutions and their staffing have been shown.

Conclusions. The state policy on health care reforming should be directed on creation of model answering to social and economic realities of Ukraine. It is necessary to introduce experience of reforming of health care system in pilot regions at a national level.

KEY WORDS: uniform medical space, pilot regions, quality of medical aid.

Рукопис надійшов до редакції 11.11.2015 p.

\section{Відомості про авторів:}

Дзюба Олександр Миколайович - д.мед.н., професор, заступник директора з наукової роботи дУ “Український інститут стратегічних досліджень МОЗ України"; служб. тел.: +38(044) 576-41-49.

Кучеренко Наталія Тимофіївна - к.е.н., завідувач відділу економічних досліджень охорони здоров'я та медичного страхування ДУ “Український інститут стратегічних досліджень МОЗ України”; служб. тел.: +38(044) 576-41-19. 